\title{
Neutron Activation Analysis and Scanning Electron Microscopy of Phytoplankton in the Coastal Zone of Crimea (The Black Sea)
}

\author{
P. S. Nekhoroshkov' ${ }^{1}$, A. V. Kravtsova1, M. V. Frontasyeva ${ }^{2 *}$, Yu. N. Tokarev ${ }^{1}$ \\ ${ }^{1}$ Department of Biophysical Ecology, Department of Biotechnology and Phytoresources, The A.O. Kovalevsky \\ Institute of Biology of the Southern Seas of the National Academy of Science of the Ukraine, Sevastopol, Ukraine \\ ${ }^{2}$ Sector of Neutron Activation Analysis and Applied Research, The Frank Laboratory of Neutron Physics, Joint \\ Institute for Nuclear Research, Dubna, Russia \\ Email: "marina@nf.jinr.ru
}

Received 28 February 2014; revised 31 March 2014; accepted 9 April 2014

Copyright () 2014 by authors and Scientific Research Publishing Inc.

This work is licensed under the Creative Commons Attribution International License (CC BY). http://creativecommons.org/licenses/by/4.0/

(c) (i) Open Access

\section{Abstract}

The physiology and ecology of planktonic organisms are influenced by the concentration, chemical speciation and resulting bioavailability of some trace metals. The determination of the elemental structure of phytoplankton is important for interpretation of physiological and functional states of coastal ecosystems. The present study is focused on the structure and elemental composition of the phytoplankton assemblages from the different coastal zones by instrumental neutron activation analysis (INAA), scanning electron microscopy (SEM) and energy-dispersive X-ray spectrometry (EDS). For the first time these complementary techniques were simultaneously applied to study the Black Sea phytoplankton. The concentrations of 45 elements in the coastal phytoplankton communities used as bioindicator of inorganic contamination of the Black Sea coastal area near Sevastopol, Ukraine, were determined. Phytoplankton samples were collected by total tows of the plankton net with $35 \mu \mathrm{m}$ pore size at 3 stations situated in polluted and relatively pristine water areas of the Sevastopol coastal zone during autumn period of the phytoplankton growth. The concentration of $\mathrm{Mg}, \mathrm{Al}, \mathrm{Sc}, \mathrm{Ti}, \mathrm{V}, \mathrm{Mn}, \mathrm{As}, \mathrm{Rb}, \mathrm{Ba}, \mathrm{Th}$ and $\mathrm{Fe}, \mathrm{Cr}$ increases exponentially from relatively pristine station to more polluted station and 10-times and 3-times greater, respectively, in the phytoplankton of the Sevastopol Bay. The rare-earth elements have relatively the same concentration values less than $1 \mu \mathrm{g} / \mathrm{g}$ and tend to accumulate in the phytoplankton from the polluted station in the Sevastopol Bay. The obtained results are in a good agreement with the elemental concentration data in the oceanic plankton, plankton communities from the White Sea and the Black Sea. Using energy-dispersive X-ray spectrometry the mineral particles of unknown origin and impurities of copper $(0.42 \%$ by weight) in the phytoplankton at the polluted station and zinc $(0.57 \%$ by weight) at the relatively pristine station were determined.

\footnotetext{
${ }^{*}$ Corresponding author.
}

How to cite this paper: Nekhoroshkov, P.S., et al. (2014) Neutron Activation Analysis and Scanning Electron Microscopy of Phytoplankton in the Coastal Zone of Crimea (The Black Sea). American Journal of Analytical Chemistry, 5, 323-334. 


\section{Keywords}

\section{Black Sea Phytoplankton, Scanning Electron Microscopy, Neutron Activation Analysis, Energy-Dispersive X-Ray Spectrometry, Trace Elements}

\section{Introduction}

Plankton (phytoplankton and zooplankton) containing organisms suspended in water and typically carried by the waves, tides and currents is very sensitive to changes in the environment; therefore it is widely used as an indicator of water quality [1]-[3]. Elemental accumulation as a dynamic process in plankton depends on concentration of elements in the environment and different processes induced by the environmental nutritional stress, which are determined by functional state of each organism [4]. Earlier it was shown that the plankton responds to the presence of heavy metals in water environment, upon that some elements inhibit and some stimulate growth of organisms and community [1] [2].

The physiology and ecology of planktonic organisms are influenced by the concentration, chemical speciation and resulting bioavailability of some trace metals such as $\mathrm{Fe}, \mathrm{Cu}, \mathrm{Zn}, \mathrm{Cd}$, and Hg. Therefore, since A.P. Vinogradov [5] determined the concentrations of $\mathrm{Ca}, \mathrm{Mg}, \mathrm{K}, \mathrm{P}, \mathrm{Fe}, \mathrm{Mn}, \mathrm{S}, \mathrm{Cl}, \mathrm{Si}, \mathrm{Br}$, and I in zooplankton sampled in the White and Barents Seas, many studies have been devoted to chemical (elemental) content of the plankton in the different regions of the World Ocean.

Goals and approaches to the study of the elemental concentration of plankton are very different. Thus, Leonova estimated the concentration of a wide range of elements in the White Sea zooplankton [6], phytoplankton and zooplankton from freshwater Siberia lakes [7] and considered their accumulation capacity and involving into geochemical processes. The ability of plankton to concentrate trace elements from its environment is used to indicate the level of coastal water pollution in different regions of the World Ocean [2] [8]-[12].

The elemental content of the Black Sea plankton has been studied for over 50 years. Thus, Vinogradova [13] studied the ability of plankton to accumulate polyvalent metals, Rozhanskaya [14] explored the distribution of $\mathrm{Mn}, \mathrm{Fe}, \mathrm{Co}, \mathrm{Ni}, \mathrm{Cu}$, and $\mathrm{Zn}$ over the food chain from plankton to the fishes, and Saenko [15] gave the data about the concentration of $\mathrm{Ti}, \mathrm{V}, \mathrm{Cr}, \mathrm{Mn}, \mathrm{Fe}$, and $\mathrm{Cu}$ in the plankton from the coastal waters of the Sevastopol region. But generally large zooplankton (more than 100 microns) and casual small amounts of phytoplankton were studied by the mentioned scientists and only up to 10 elements were determined.

Marine coastal area of the Sevastopol region is exposed to various types of pollution. Heavy metals and other pollutants enter into the coastal waters with the surface and underwater runoff [16]. Heavy metals also come from old ships, industrial and agricultural facilities. The grain terminal in the Sevastopol Bay, where several large vessels dock every day, is one more source of the coastal waters pollution with trace elements (ballast waters, paint and plank materials, fuels). Secondary pollution takes place during the storm wave when buried fuel and oil are getting up from the bottom sediments to the surface [16].

Since the anthropogenic impact on the plankton communities increases, the present study is focused on the elemental composition of the phytoplankton assemblages from the polluted zone of the Sevastopol Bay and from relatively pristine deep water coastal station.

To determine structure and elemental composition of phytoplankton and suspended particles, the methods of scanning electron microscopy (SEM), energy-dispersive X-ray spectrometry (EDS) and instrumental neutron activation analysis (INAA) were used.

The multi-element INAA at the reactor IBR-2 of FLNP JINR with its low temperature in the irradiation channels is particularly efficient in the analysis of biological samples [17]. The SEM/EDS also is widely applied in biological analysis [18]. To our knowledge, these two complementary techniques were never simultaneously applied to study the Black Sea phytoplankton.

\section{Materials and Methods}

\subsection{Sampling and Sample Preparation}

The samples of phytoplankton were collected in the autumn of 2013 during its active growth at three coastal sta- 
tions, where the first and the second stations are located in a relatively pristine zone, and the third one in the polluted zone of the Sevastopol Bay (Figure 1). Stations 1 and 2 are situated in deep waters (the depth is more than 40 meters) and station 3 is in the entrance of the Sevastopol Bay (12 m depth). The characteristics of the sampling sites are shown in Table 1.

The phytoplankton was collected by means of the vertical tows of the phytoplankton Nansen net $(35 \mu \mathrm{m}$ mesh size) [19].

Sampling sites were chosen in compliance with the data of hydrochemical monitoring and the quality of water according to the trophical index (TRIX) of the coastal waters in the Sevastopol region [20]. Samples were filtered on paper filters with $10 \mu \mathrm{m}$ pore size in the laboratory conditions. The sea-salt particles were dissolved and washed out after the treatment with distilled water. Then the filters with phytoplankton were dried at room temperature and subdivided for INAA and SEM/EDS.

\subsection{Analysis}

Elemental analysis of the phytoplankton samples was carried out by INAA at the reactor IBR-2 of FLNP, JINR. The analytical procedures and the basic characteristics of the employed experimental facility are described in detail elsewhere [17]. The samples of about $0.3 \mathrm{~g}$ were packed in polyethylene bags for short-term irradiation and in aluminum cups for long-term irradiation.

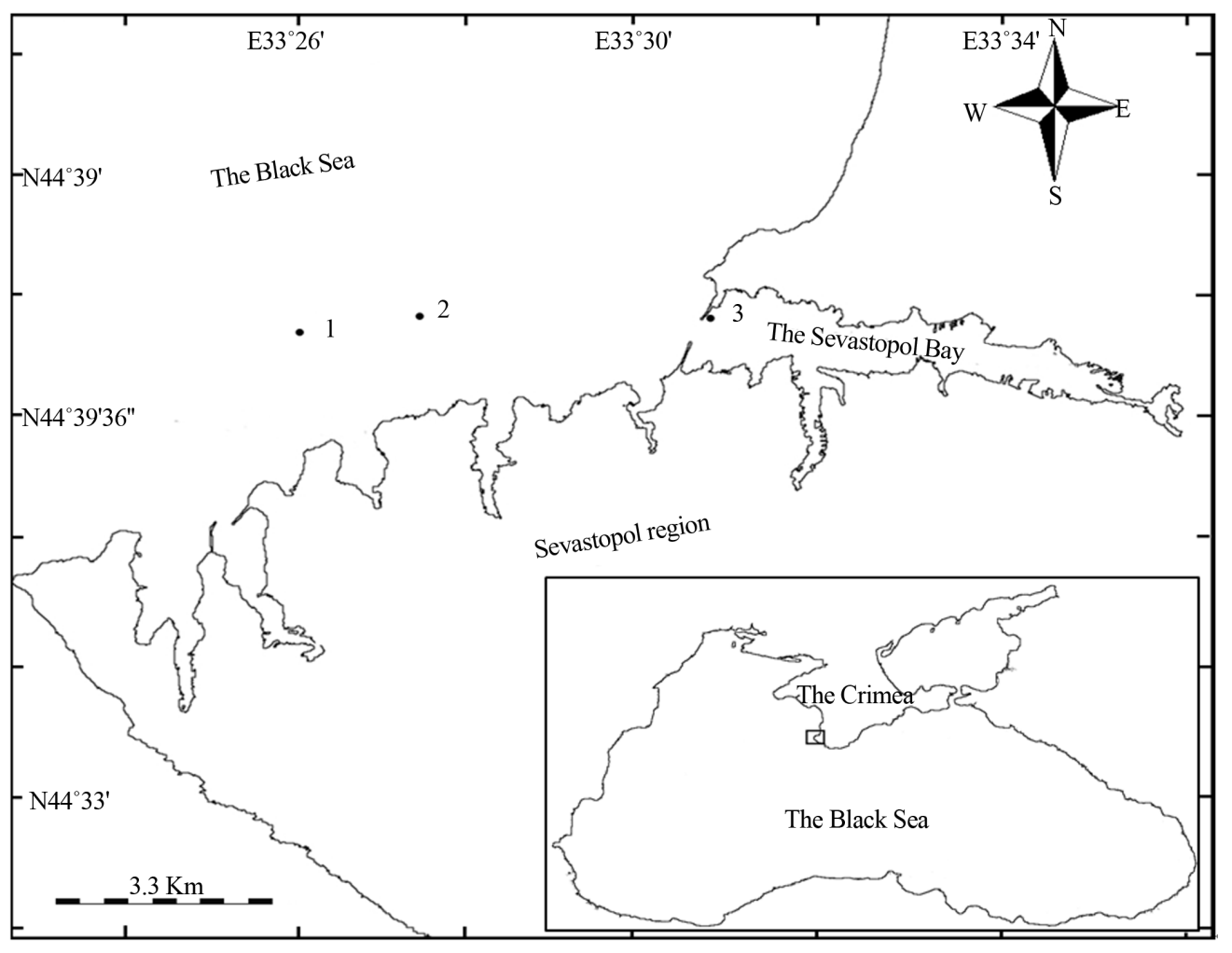

Figure 1. Sampling sites in the coastal zone of the Sevastopol region (Crimea, the Black Sea).

Table 1. Sampling stations.

\begin{tabular}{|c|c|c|c|c|c|}
\hline Number of & \multicolumn{2}{|c|}{ Coordinates } & \multirow{2}{*}{$\begin{array}{c}\text { Maximal } \\
\text { depth, m }\end{array}$} & \multirow{2}{*}{$\begin{array}{c}\text { Distance from } \\
\text { shore, } m\end{array}$} & \multirow{2}{*}{$\begin{array}{c}\begin{array}{c}\text { Filtered water } \\
\text { volume, } \mathrm{m}^{3}\end{array} \\
10.75\end{array}$} \\
\hline 1 & $44^{\circ} 37^{\prime} 51.6^{\prime \prime}$ n. 1. & $33^{\circ} 26^{\prime} 20.2^{\prime \prime}$ e. 1. & & & \\
\hline 2 & $44^{\circ} 37^{\prime} 45.01^{\prime \prime}$ n. 1. & $33^{\circ} 27^{\prime} 22.46^{\prime \prime}$ e. 1. & 45 & 2010 & 8.60 \\
\hline 3 & $44^{\circ} 37^{\prime} 30.21^{\prime \prime}$ n. 1. & $33^{\circ} 30^{\prime} 41.51^{\prime \prime}$ e. 1. & 12 & 141 & 3.22 \\
\hline
\end{tabular}


To determine the short-lived isotopes of $\mathrm{Mg}, \mathrm{Al}, \mathrm{Cl}, \mathrm{Ca}, \mathrm{Ti}, \mathrm{V}, \mathrm{Mn}, \mathrm{Cu}$, and I the samples were irradiated for $3 \mathrm{~min}$ in the reactor channel with a neutron flux density of $1.3 \cdot 10^{12} \mathrm{n} /\left(\mathrm{cm}^{2} \mathrm{~s}\right)$. Gamma spectra of induced activity were measured for $12-15 \mathrm{~min}$ after $20 \mathrm{~min}$ of decay. The elemental contents of the long-lived isotopes of $\mathrm{Na}, \mathrm{K}$, Sc, Cr, Fe, Co, Ni, Zn, As, Se, Br, Rb, Sr, Zr, Mo, Ag, Sb, Cs, Ba, La, Ce, Nd, Sm, Gd, Tb, Tm, Yb, Hf, Ta, W, $\mathrm{Au}$, Th, and $\mathrm{U}$ were determined using epithermal neutrons in a cadmium-screened irradiation channel with a neutron flux density of $1.6 \cdot 10^{12} \mathrm{n} /\left(\mathrm{cm}^{2} \cdot \mathrm{s}\right)$. Samples were irradiated for $90 \mathrm{~h}$, repacked and then measured twice after 4 - $5 \mathrm{~d}$ of decay during 30 minutes and after 20 days of decay during 1.5 hours.

To process gamma spectra of induced activity and to calculate concentrations of elements in the samples, software developed at FLNP, JINR was used [21]. The uncertainties in the determined concentrations were in the range of $5 \%-15 \%$, and of $30 \%$ or more for those elements which concentrations in the samples were at the detection limit, e.g. Nd, Tm, Yb.

Quality control was provided by using NIST standard reference materials: 433, 690CC, 1547, 1572, 1632b, 1633b, 2709, 2710 irradiated in the same conditions together with the samples under investigation.

The SEM/EDS of the phytoplankton specimens were performed using SMA Quanta 3D FEG instrument in the Laboratory of microscopy of Skolkovo Institute of Science and Technology. The SEM images of selected area of phytoplankton and spots were obtained simultaneously with the rapid quantitative analysis of the elemental concentrations.

\section{Results and Discussion}

The concentrations of 45 elements determined by INAA in phytoplankton of the coastal zone of the Black Sea (stations 1-3), as well as comparative literature are given in Table 2.

The elemental concentrations in the phytoplankton were calculated for the coastal stations in relatively pristine water area (station 1), in relatively polluted water area (station 3 in the Sevastopol Bay) and in the intermediate zone (station 2) (Table 2). Our data were compared with the elemental concentrations in phytoplankton from the coastal waters of different regions of the World Ocean [15] [22] [23].

The concentrations of some elements ( $\mathrm{Na}, \mathrm{K}$, and $\mathrm{Ca}$ ) in the plankton from the White Sea [23] exceed our results because after filtration their samples were not washed by distilled water.

The concentrations of macro- and trace elements which are significantly accumulated in phytoplankton are shown in Figure 2.

As follows from the results obtained, in phytoplankton the concentration of major elements from the most polluted shallow water station 3 is considerable higher than in phytoplankton from the deeper stations. For example, the concentration of such elements as $\mathrm{Mg}, \mathrm{Al}, \mathrm{Sc}, \mathrm{Ti}, \mathrm{V}, \mathrm{Mn}, \mathrm{As}, \mathrm{Rb}, \mathrm{Ba}$, and Th (Figure 2 and Figure 3) exponentially increases towards more polluted station 3 by 5-10-fold. However, concentrations of $\mathrm{Fe}$ and $\mathrm{Cr}$ in the phytoplankton from the Sevastopol Bay are only 2-fold greater.

The high content of polyvalent metals in the phytoplankton is due to the high concentrating ability of the phytoplankton. Thus, according to [15], concentrations of $\mathrm{Mn}, \mathrm{Fe}, \mathrm{Ti}$ and $\mathrm{Cu}, \mathrm{Cr}$ in plankton (phyto- and zooplankton) collected in September 1969 in the Sevastopol Bay and seaward were 10-fold and 2-3-fold greater, respectively, than in the marine macrophytes collected at the same sampling site. Concentration of such elements as $\mathrm{Na}, \mathrm{Cl}, \mathrm{K}, \mathrm{Br}, \mathrm{Mo}, \mathrm{Ag}, \mathrm{Sb}, \mathrm{Au}$, and $\mathrm{W}$ is relatively constant in the phytoplankton from all three stations (Table 2). It is probably due to their homogeneous distribution in the coastal waters in this period. The content of iodine is constant in the phytoplankton from the deep water stations (1 and 2), but at the station 3 it is 10-fold greater. On the one hand, this is due to the presence of large number of macroalgaethalli (bodies) containing large amounts of I in the shallow water station. On the other hand, Vinogradov [5] notes the high content of iodine in diatoms that intensively grow in the shallow waters. The concentrations of the poorly mobile elements (Sc, Ti, V, Mn, Fe, Co, Ga, Rb, Y, Zr, Nb, Cs, Ba, lanthanides, Hf, Ta, and Th) are characteristic for the terrigenous component comprising $20 \%-30 \%$ of the ash content in the seston, which is one order of magnitude higher in the seston [6]. A significant fraction of the terrigenous admixture was observed in the seston from the station 3. It evidences for a rather large difference (in the range of one order of magnitude) in values of elemental concentrations, indicators of the mineral sludge component of the suspension containing REE, Sc, Al, Ta, and Th [6].

The concentration values of the rare-earth elements are relatively of the same order (about $1 \mu \mathrm{g} / \mathrm{g}$ ) (Figure 4), 
Table 2. Elemental concentrations in the plankton $(\mu \mathrm{g} / \mathrm{g})$.

\begin{tabular}{|c|c|c|c|c|c|c|}
\hline \multirow{3}{*}{ Elements } & \multirow{2}{*}{\multicolumn{3}{|c|}{$\begin{array}{l}\text { Phytoplankton } \\
\text { Present study (INAA), the Black Sea }\end{array}$}} & \multicolumn{3}{|c|}{ Total plankton } \\
\hline & & & & \multirow[t]{2}{*}{ The Black Sea [15] } & \multirow[t]{2}{*}{ The World Ocean [22] } & \multirow[t]{2}{*}{ The White Sea [23 } \\
\hline & St 1 & St 2 & St 3 & & & \\
\hline $\mathrm{Na}$ & $2025 \pm 52$ & $715 \pm 19$ & $1095 \pm 29$ & & 33000 & 63000 \\
\hline $\mathrm{Mg}$ & $173 \pm 6$ & $546 \pm 19$ & $2370 \pm 69$ & & 94000 & \\
\hline $\mathrm{Al}$ & $<309$ & $951 \pm 26$ & $4421 \pm 118$ & & 62 & \\
\hline S & $50.8 \pm 23.5$ & $25.4 \pm 11.6$ & $4.6 \pm 3.2$ & & 8300 & \\
\hline $\mathrm{Cl}$ & $2650 \pm 233$ & $1520 \pm 134$ & $1520 \pm 135$ & & 4700 & \\
\hline $\mathrm{K}$ & $1380 \pm 787$ & $732 \pm 288$ & $1810 \pm 455$ & & 52000 & 13000 \\
\hline $\mathrm{Ca}$ & $<811$ & $349 \pm 35$ & $4379 \pm 386$ & & 14000 & 6000 \\
\hline Sc & $<0.03$ & $0.33 \pm 0.10$ & $0.75 \pm 0.23$ & & 0.07 & 0.45 \\
\hline $\mathrm{Ti}$ & $15 \pm 4$ & $64 \pm 10$ & $291 \pm 25$ & $45-201$ & 10 & 400 \\
\hline V & $0.20 \pm 0.02$ & $1.4 \pm 0.1$ & $6.6 \pm 0.3$ & $6-15$ & 3.5 & 3 \\
\hline $\mathrm{Cr}$ & $5.16 \pm 1.15$ & $11.86 \pm 1.24$ & $15.76 \pm 1.51$ & $30-69$ & 1.8 & 620 \\
\hline Mn & $3.0 \pm 0.2$ & $6.0 \pm 0.4$ & $28.4 \pm 1.5$ & $3-63$ & 20 & 80 \\
\hline $\mathrm{Fe}$ & $1370 \pm 198$ & $1580 \pm 173$ & $4220 \pm 295$ & $3310-9670$ & 160 & 2460 \\
\hline $\mathrm{Ni}$ & $0.43 \pm 0.02$ & $0.28 \pm 0.02$ & $0.81 \pm 0.03$ & & 0.4 & 0.9 \\
\hline Co & $0.6 \pm 0.1$ & $15.7 \pm 1.1$ & $15.1 \pm 1.2$ & & 1.4 & 3.5 \\
\hline $\mathrm{Cu}$ & $91.4 \pm 32.4$ & $43.1 \pm 15.7$ & $117 \pm 42$ & $38-187$ & 12 & 43 \\
\hline $\mathrm{Zn}$ & $205 \pm 20$ & $86 \pm 8$ & $124 \pm 11$ & & 39 & 362 \\
\hline As & $0.11 \pm 0.01$ & $0.59 \pm 0.04$ & $1.8 \pm 0.1$ & & 15 & 13 \\
\hline Se & $0.26 \pm 0.06$ & $<0.13$ & $0.04 \pm 0.01$ & & 0.063 & 0.4 \\
\hline $\mathrm{Br}$ & $59.1 \pm 7.1$ & $28.2 \pm 3.4$ & $64.7 \pm 7.7$ & & 440 & 2000 \\
\hline $\mathrm{Rb}$ & $0.20 \pm 0.12$ & $2.7 \pm 0.5$ & $7.4 \pm 1.4$ & & 1.8 & 7 \\
\hline $\mathrm{Sr}$ & $6.3 \pm 0.8$ & $6.8 \pm 0.7$ & $15.1 \pm 1.4$ & & 1100 & 106 \\
\hline $\mathrm{Zr}$ & $7.0 \pm 4.7$ & $8.0 \pm 3.5$ & $16.7 \pm 6.5$ & & 0.7 & 3.6 \\
\hline Mo & $0.2 \pm 0.07$ & $0.19 \pm 0.09$ & $0.24 \pm 0.08$ & & 0.39 & 0.2 \\
\hline $\mathrm{Ag}$ & $0.07 \pm 0.01$ & $0.07 \pm 0.02$ & $0.05 \pm 0.013$ & & 0.22 & \\
\hline Sn & $21.3 \pm 2.6$ & $1.3 \pm 0.4$ & $1.8 \pm 0.5$ & & 0.29 & 1.2 \\
\hline $\mathrm{Sb}$ & $0.74 \pm 0.03$ & $0.28 \pm 0.01$ & $0.37 \pm 0.04$ & & 0.16 & 1.8 \\
\hline I & $1.2 \pm 0.2$ & $2.2 \pm 0.4$ & $22.0 \pm 4.0$ & & 1020 & 139 \\
\hline $\mathrm{Ba}$ & $33.6 \pm 8.9$ & $<9.9 \pm 4.5$ & $48.7 \pm 13.4$ & & 19 & 28 \\
\hline Cs & $0.012 \pm 0.01$ & $0.18 \pm 0.01$ & $0.47 \pm 0.02$ & & 0.072 & 0.6 \\
\hline $\mathrm{La}$ & $0.115 \pm 0.025$ & $0.822 \pm 0.055$ & $2.1 \pm 0.12$ & & 0.14 & 1.18 \\
\hline $\mathrm{Ce}$ & $0.6 \pm 0.3$ & $1.2 \pm 0.5$ & $3.7 \pm 1.1$ & & 0.23 & 2.6 \\
\hline $\mathrm{Nd}$ & $3.1 \pm 1$ & $0.5 \pm 0.4$ & $1.1 \pm 1.3$ & & & \\
\hline $\mathrm{Sm}$ & $0.6 \pm 0.2$ & $0.7 \pm 0.2$ & $0.6 \pm 0.2$ & & & \\
\hline $\mathrm{Gd}$ & $<0.6$ & $4.0 \pm 1.2$ & $1.8 \pm 0.6$ & & & \\
\hline $\mathrm{Tb}$ & $<0.01$ & $0.02 \pm 0.01$ & $0.06 \pm 0.02$ & & & 0.022 \\
\hline Dy & $<0.14$ & $0.11 \pm 0.03$ & $0.32 \pm 0.11$ & & & \\
\hline $\mathrm{Tm}$ & $0.04 \pm 0.01$ & $0.02 \pm 0.01$ & $0.16 \pm 0.02$ & & & \\
\hline $\mathrm{Yb}$ & $0.14 \pm 0.07$ & $0.11 \pm 0.04$ & $0.53 \pm 0.12$ & & & 0.13 \\
\hline $\mathrm{Hf}$ & $<0.02$ & $0.19 \pm 0.06$ & $0.34 \pm 0.1$ & & & 0.11 \\
\hline Та & $0.002 \pm 0.001$ & $0.03 \pm 0.01$ & $0.05 \pm 0.02$ & & & 0.06 \\
\hline $\mathrm{W}$ & $0.3 \pm 0.1$ & $0.2 \pm 0.1$ & $0.3 \pm 0.1$ & & 0.035 & \\
\hline $\mathrm{Au}$ & $0.004 \pm 0.001$ & $0.002 \pm 0.001$ & $0.002 \pm 0.001$ & & 0.008 & \\
\hline Th & $<0.03$ & $0.30 \pm 0.01$ & $0.70 \pm 0.02$ & & 0.1 & 0.28 \\
\hline $\mathrm{U}$ & $2.4 \pm 0.2$ & $1.9 \pm 0.2$ & $0.7 \pm 0.1$ & & 0.8 & \\
\hline
\end{tabular}




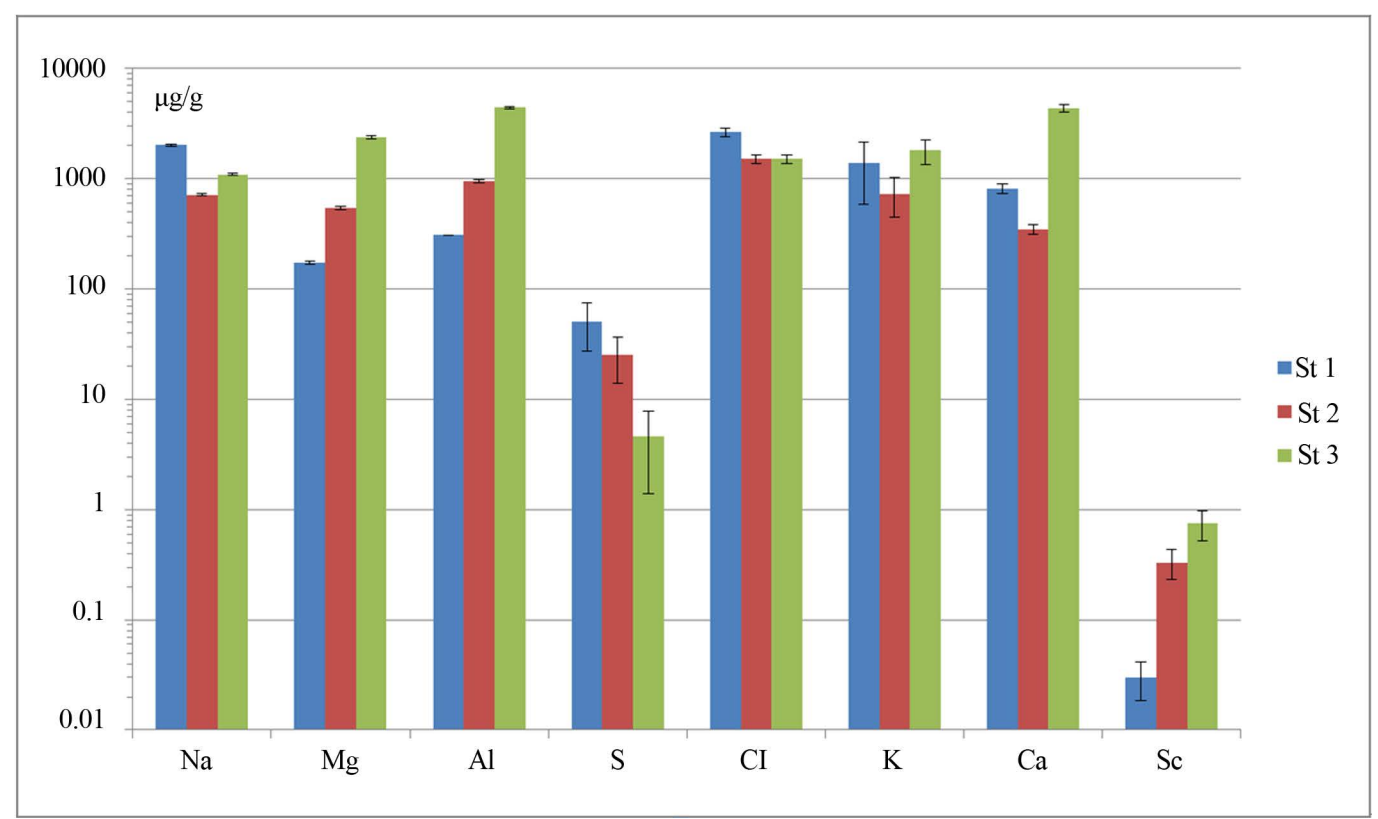

Figure 2. Concentrations of major elements in phytoplankton $(\mu \mathrm{g} / \mathrm{g})$ determined by INAA at 3 stations $(\log$ scaling).

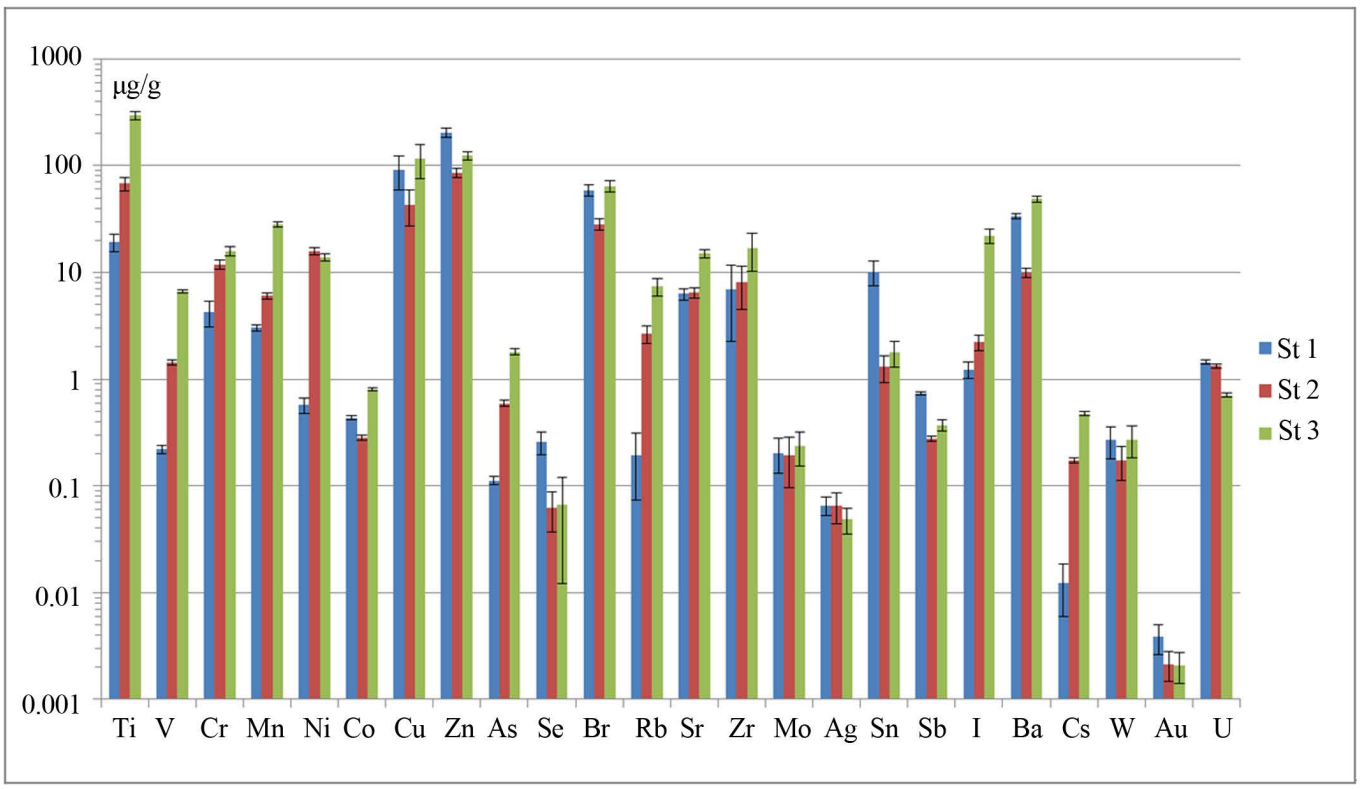

Figure 3. Concentrations of some elements in the phytoplankton samples (log scaling).

and they tend to accumulate in the phytoplankton from the polluted station in the Sevastopol Bay. This is probably due to a significant amount of disturbed bottom and terrigenous sediments in the phytoplankton samples.

Concentrations of the most elements in the phytoplankton at all stations are in a good agreement with the concentrations in the total phyto- and zooplankton from the other regions of the World Ocean (with other salinity and other hydrological features) (Table 2).

The Black Sea phytoplankton community consists of many different species. The trophic structure, seasonal variability of phytoplankton community and quality of water (for example transparency on disk Secchi depth) are mostly determined by the variability and dynamics of two groups of phytoplankton (diatoms and dinoflagellates). The diatoms (Bacilliariophyta) are small autotrophic cells which consist of $\mathrm{SiO}_{2}$ and which can live in the 
polluted coastal and estuarine waters in the photic zone. The phylum Bacilliariophyta is distinguished by the presence of an inorganic cell-wall composed of silica (hydrated $\mathrm{SiO}_{2}$ ).

The collected phytoplankton samples contain organic (both living phyto- and zooplankton and detrital), inorganic particles, and clay minerals; all together called as seston [24]. Therefore, we should take into account that the SEM images show aggregates of mineral particles, parts and tissues of decaying indefinable organisms and living plankton cells (Figures 5-7).

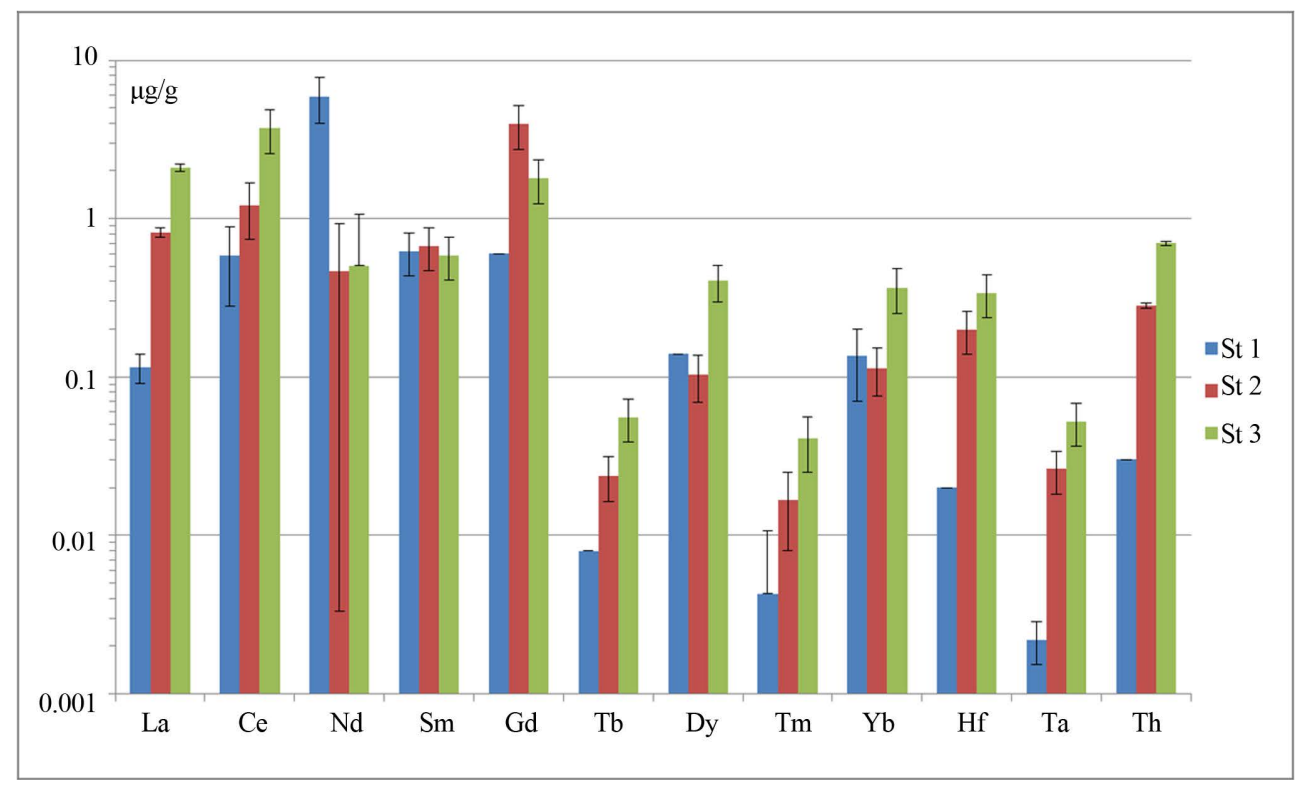

Figure 4. Concentrations of the rare earth elements in the phytoplankton from the 3 stations (log scaling).

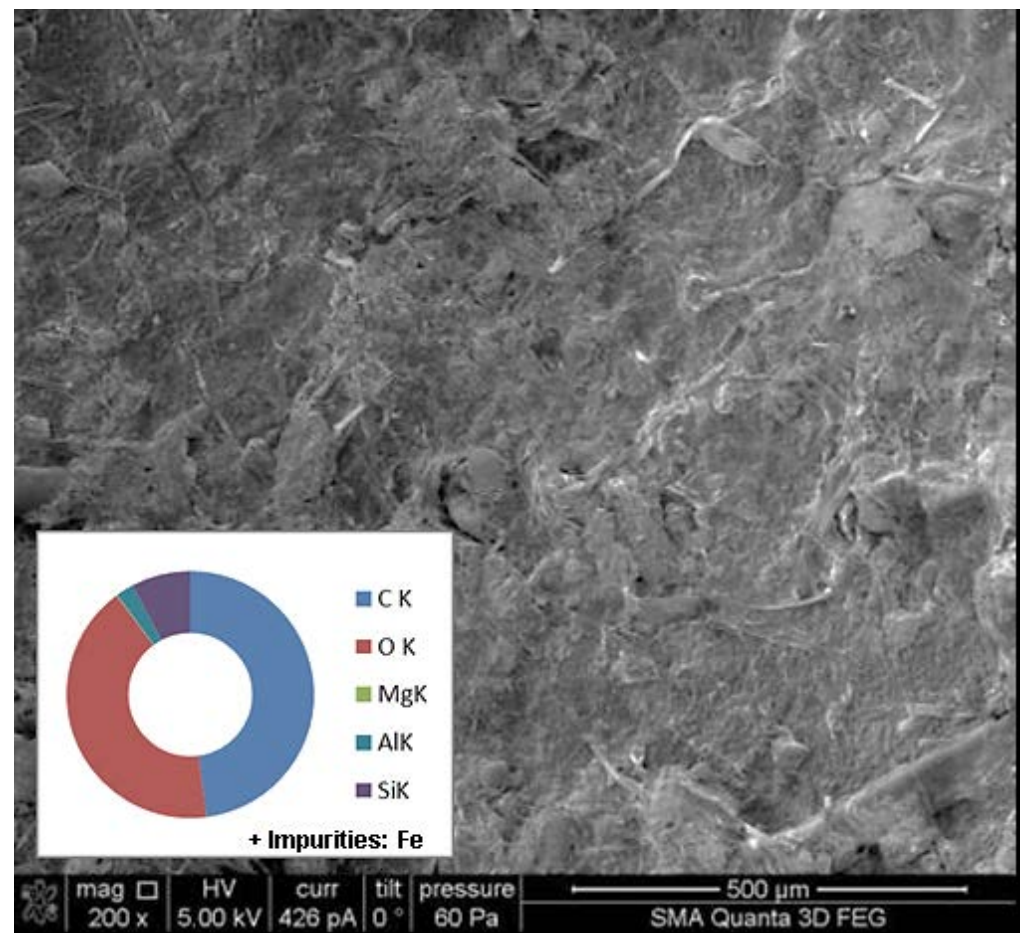

Figure 5. The SEM image and elemental concentration (EDS) for full area of specimen from station 1 . 


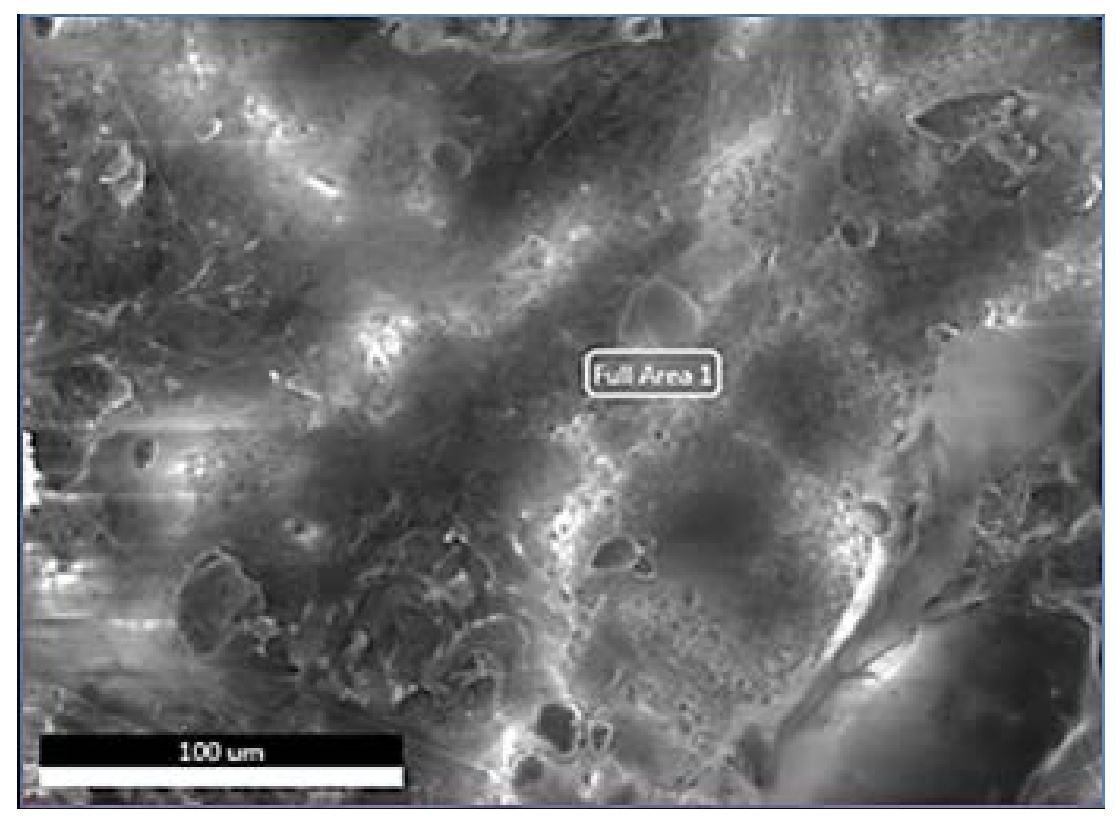

Figure 6. The SEM image of $300 \mu \mathrm{m}$ phytoplankton specimen from station 2.

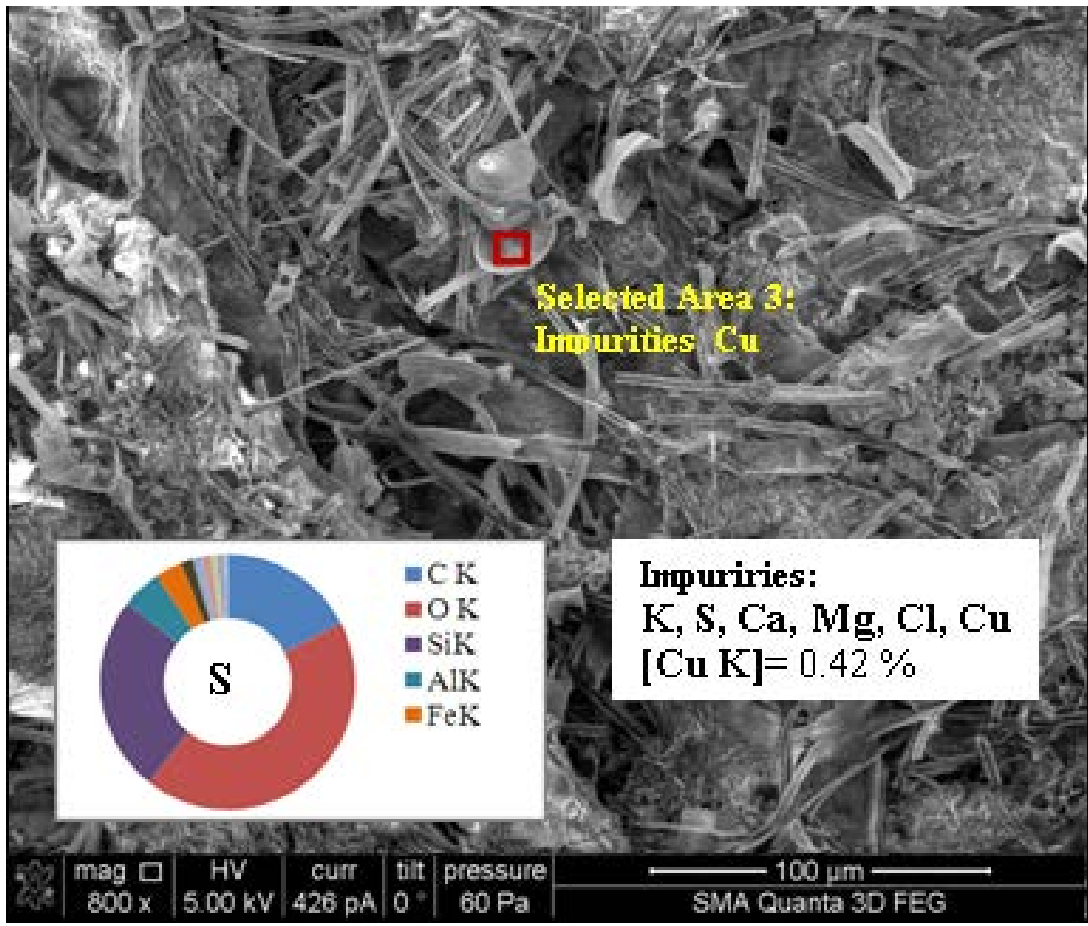

Figure 7. $300 \mu \mathrm{m}$ phytoplankton specimen from the station 3 and relative concentration levels for the selected area 3 with marked impurities (EDS).

In the open coastal zone (stations 1 and 2) the dynamic water circulation is different in different seasons. In summer-autumn the relative biodiversity of phytoplankton community is greater in the deeper coastal water areas than at the stations located in the bay. Therefore, homotypical phytoplankton aggregation with only several species of diatoms grows in the Sevastopol Bay at a depth less than $15 \mathrm{~m}$. SEM images of specimens from the shallow-water station 3 show that diatoms have line, curve and boxes shapes (Figure 7). The number of dinoflagellates is less than a number of other species at this station, because dinoflagellates usually escaping polluted 
shallow water areas (e.g. Figures 5-7).

Zooplankton in shallow waters (station 3) is practically absent, and at stations 1 and 2 in the deep water areas zooplankton organisms occur in samples with products of their living (fecal pellets, pieces of tissues).

Thus, a lot of diatoms phytoplankton algae of line and box shapes were observed in the specimen from the polluted station 3, but in the specimen from the relatively pristine deep water stations 1 and 2 mature adults of zooplankton and heterotrophic dinoflagellates were also found (Figure 5 and Figure 6). This fact shows that plankton (both phyto- and zooplankton) community in polluted shallow water coastal areas (station 3) has just a several number of species compared to relatively pristine deep water areas.

Organogenic elements such as $\mathrm{C}, \mathrm{O}, \mathrm{N}, \mathrm{H}, \mathrm{P}$, and S compose biomass of living organisms. They form proteins, carbohydrates, lipids, nucleic acids and others biologically active compounds present in each cell of phytoplankton. Essential elements such as $\mathrm{Ca}, \mathrm{K}, \mathrm{Na}, \mathrm{Cl}, \mathrm{Zn}, \mathrm{Mn}, \mathrm{Mo}$, I, Se, Mg, Fe, Cu, and Co are responsible for the physiological processes of cells [25]. However, high concentration of these elements in the environmental water can slow down the vital processes, such as photosynthesis in chloroplasts in the phytoplankton cells. Several diatom algae are covered with $\mathrm{SiO}_{2}$, and some elements might be are embedded in their shells or tissues. Such elements have been found by EDS (Figures 7-9).

The elemental concentrations on the surface of the specimen were estimated by the EDS in homogeneous material of each sample. The random selection of several spots in the field of specimen helps one to study a particulate elemental structure of the sample (Figure 7).

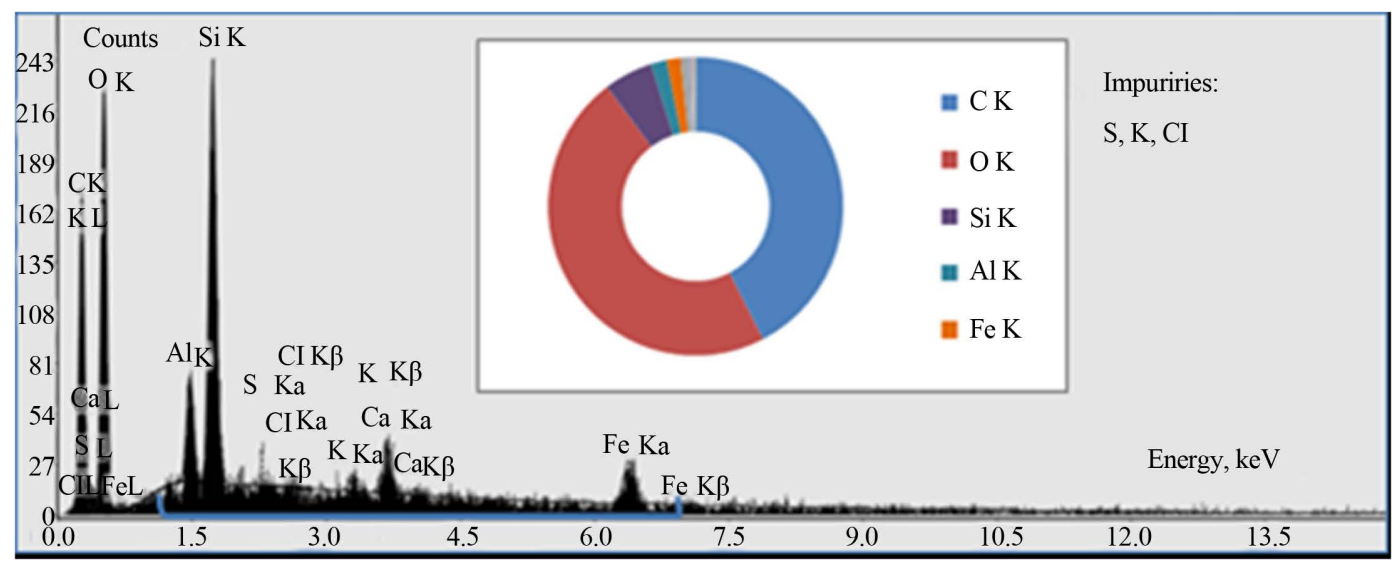

Figure 8. X-ray spectrum of the $300 \mu \mathrm{m}$ phytoplankton specimen from the station 2 (blue line marks biogenic or mineral microelements with concentration less than $6 \%$ by weight) (EDS).

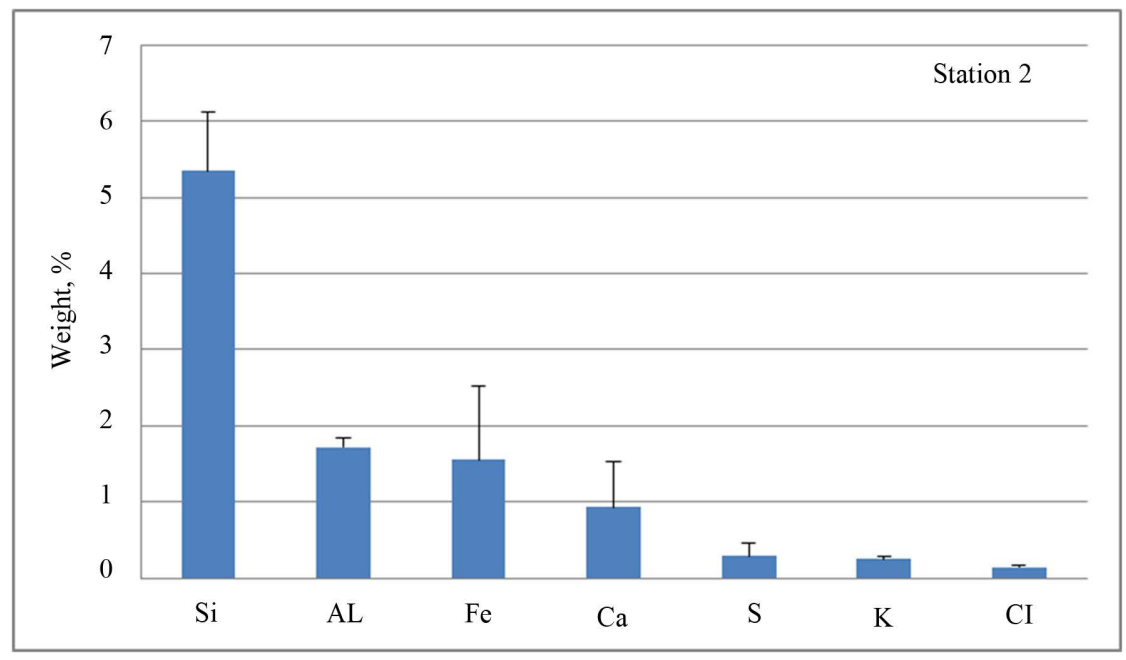

Figure 9. Relative levels of the major element concentrations in the $300 \mu \mathrm{m}$ specimen from the station 2 (EDS). 
All the studied specimens had relatively equal elemental concentration levels, both in full areas and randomly selected spots. Using SEM/EDS, we observed several spots with non-typical concentration features. For example, we observed spots without carbon (obviously of the mineral origin), with the oxides of $\mathrm{Si}, \mathrm{Al}, \mathrm{Fe}$, and $\mathrm{Mg}$; the calcium particles; biogenic particles with the $\mathrm{Cu}(0.42 \%$ by weight) (Figure 7$)$ and $\mathrm{Zn}(0.57 \%$ by weight) impurities of the unknown origin. The high concentrations of copper and zinc are likely associated with the anthropogenic pollution sources.

$\mathrm{Ca}, \mathrm{Al}, \mathrm{Fe}, \mathrm{Mg}, \mathrm{K}, \mathrm{Cl}$, and Na determined by INAA showed the highest concentrations in the plankton samples. $\mathrm{Ca}, \mathrm{Mg}, \mathrm{K}, \mathrm{Cl}$, and $\mathrm{Na}$ are the most abundant ions of seawater, and by weight these ions constitute 99\% of sea salts. High levels of $\mathrm{Si}$ and $\mathrm{Al}$ which were detected by the EDS and INAA confirm hypothesis that the silicon and aluminum cycles in the oceans are linked through the activity of diatoms [26]. Iron is undoubtedly the most versatile and important trace element for biochemical catalysis. The particulate and colloidal fraction comprises oxides, aluminosilicates and possibly organic forms [27].

The differences between concentrations of the major elements which were determined by different methods are associated with properties and features of the EDS and INAA. The detection limits of the elements determined by EDS are about 30 - 3000 ppm ( $>1 \%$ by weight) as they depend on the energy and spatial resolution of the apparatus and they are greater compared to the detection limits and accuracy of INAA. However, elemental concentrations in the small patches and spots in the surface of the specimen were determined by the EDS. Therefore, the EDS is a rough and ready tool for the identification of the elements and analysis of the spatial elemental structure.

\section{Conclusions}

1) The results obtained show that the concentrations of major elements in phytoplankton from the shallow water station 3 are greater than those in phytoplankton from the deeper stations. It means that phytoplankton from the Sevastopol Bay is involved in geochemical processes of the coastal elemental accumulation. The spatial distribution of terrigenous particles may therefore reflect the accumulation areas for such aggregates, although it could also derive from lateral injection of resuspended sediment from the nearby continental shelf.

2) The concentrations of $\mathrm{Mg}, \mathrm{Al}, \mathrm{Sc}, \mathrm{Ti}, \mathrm{V}, \mathrm{Mn}, \mathrm{As}, \mathrm{Rb}, \mathrm{I}, \mathrm{Ba}, \mathrm{Th}$ and $\mathrm{Fe}, \mathrm{Cr}$ increase exponentially from the relatively pristine station 1 to most polluted station 3, and they are 10- and 3-fold greater in the phytoplankton of the Sevastopol Bay, respectively. This data justifies the opinion about the specific geochemical condition of the Sevastopol Bay that is typical for the marginal areas and appears also in increased concentrations of biophilic elements of the Fe group.

3) Concentrations of $\mathrm{Na}, \mathrm{Cl}, \mathrm{K}, \mathrm{Br}, \mathrm{Mo}, \mathrm{Ag}, \mathrm{Sb}, \mathrm{Au}$, and $\mathrm{W}$ are relatively constant in the phytoplankton from all three stations due to their homogeneous distribution in the coastal waters. Elements such as $\mathrm{Na}, \mathrm{K}, \mathrm{Br}, \mathrm{Ag}$, $\mathrm{Au}$ are known to be trace elements concentrated by biological processes in plants [28]. However, elements such as $\mathrm{Sc}, \mathrm{Ti}, \mathrm{V}$, Th, Mo, $\mathrm{W}$ and others are not known to be concentrated by biological processes so some other sources of association may be indicated. Physical adsorption and entrapment of colloidal mineral matter by the gelatinous matrix of the diatoms are possible.

4) The concentration of rare-earth elements is relatively the same (less than $1 \mu \mathrm{g} / \mathrm{g}$ ) and it tends to accumulate in the phytoplankton from the polluted station in the Sevastopol Bay, most probably, due to the significant amount of disturbed bottom and terrigenous sediments in the phytoplankton samples.

5) The SEM/EDS allowed determination of mineral particles of the unknown origin and impurities of copper ( $0.42 \%$ by weight) at the shallow water station 3 and zinc ( $0.57 \%$ by weight) at the deep station 1 .

6) A lot of diatoms phytoplankton microalgae of line and box shapes (ruderal species) were observed in the specimen from the station 3 in polluted area, but in the specimen from relatively pristine deep water stations 1 and 2 only mature adults of zooplankton and heterotrophic dinoflagellates were found.

Our results are in a good agreement with the elemental concentrations in phytoplankton from the other regions of the World Ocean. Phytoplankton in the coastal area of the Sevastopol region is experiencing anthropogenic impact, which is reflected in the elemental composition of phytoplankton and species structure. With simple modifications to the sampling and analytical techniques described here, size-fractionated phytoplankton and particulate concentrations for a broad suite of metals can be determined in a range of oceanic regimes, from productive coastal and estuarine environments to oligotrophic offshore waters.

Estimation of the elemental concentration levels in phytoplankton is an important part of the studying and un- 
derstanding the pollution processes, because it shows ambient side of the human activity and the environmental influence on the state of the relatively close community of phytoplankton. The study of the elemental concentrations in phytoplankton assemblages with the estimation of their functional role in the polluted coastal areas will be continued.

This study is a part of the complex research of the effect of pollution on the phytoplankton in the coastal waters of the Crimean peninsula in Sevastopol region and it was carried out in the framework of the monitoring program of the Black Sea coastal areas by the A.O. Kovalevsky Institute of Biology of the Southern Seas (IBSS). The findings of this study may serve as a background for a future complex environmental monitoring of the coastal waters of the Crimea where the data on concentrations of the elements and the biophysical parameters of phytoplankton assemblages are used for assessment of the coastal marine ecosystem.

\section{References}

[1] Davies, R.M. and Jensen, L.M. (1974) Zooplankton Entrainment at Three Mid-Atlantic Power plants. Journal of the Water Pollution Control Federation, 47, 2130-2142.

[2] Overnell, J. (1976) Inhibition of Marine Algal Photosynthesis by Heavy Metals. Marine Biology, 38, 335-342. http://dx.doi.org/10.1007/BF00391373

[3] Boyer, J.N., Kelble, C.R., Ortner, P.B. and Rudnick, D.T. (2009) Phytoplankton Bloom Status: Chlorophyll A Biomass as an Indicator of Water Quality Condition in the Southern Estuaries of Florida, USA. Ecological Indicators, 95, s56s67. http://dx.doi.org/10.1016/j.ecolind.2008.11.013

[4] Sheue-Duan, L., Pei-Chung, C. and Hoang-Kao, H. (2003) Benthic Algae as Monitors of Heavy Metals in Various Polluted Rivers by Energy Dispersive X-Ray Spectrometer. Journal of Environmental Science and Health. Part A-Toxic/Hazardous Substances \& Environmental Engineering, A38, 855-866. http://dx.doi.org/10.1081/ESE-120018596

[5] Vinogradov, A.P. (1936) Elementary Chemical Composition of Marine Organisms. (in Russian) Pt. 1. Laboratoire de Biogeochimieprèsl'Acad. des Science, U.R.S.S., Travaux, 3, 63-278.

[6] Leonova, G.A., Bobrov, V.A., Bogush, A.A. and Bychinskii, V.A. (2013) Concentration of Chemical Elements by Zooplankton of the White Sea. Marine Biology, 53, 54-70.

[7] Leonova, G.A., Bobrov, V.A. and Bogush, A.A. (2006) Estimation of the Geochemical Background and Antropogenic Pollution of the Plankton by Microelement Composition (by the Example of the Western Siberia Lakes). Bioindicators in Monitoring of Freshwater Ecosystems: Abstracts International Conference S-P., 91-92.

[8] Martin, J.H. and Knauer, G.A. (1973) The Elemental Composition of Plankton. Geochim. Et Cosmochim. Acta, 37, 16391653. http://dx.doi.org/10.1016/0016-7037(73)90154-3

[9] Jensen, A., Rystad, B. and Melson, S. (1974) Heavy Metal Tolerance of Marine Phytoplankton. I. The Tolerance of Three Algal Species to Zinc in Coastal Sea Water. Journal of Experimental Marine Biology and Ecology, 15, 145-157. http://dx.doi.org/10.1016/0022-0981(74)90040-9

[10] Hester, K. and Boyle, E. (1982) Water Chemistry Control of Cadmium Content in Recent Benthic Foraminifera. Nature, 298, 260-262. http://dx.doi.org/10.1038/298260a0

[11] Brzezinska, A., Trzosinska, A., Zmijewska, W. and Wodkiewicz, L. (1984) Trace Metals in Some Organisms from the Southern Baltic. Oceanologia, 18, 79-94.

[12] McCormick, P.V. and Cairns, J. (1994) Algae as Indicators of Environmental Change. Journal of Applied Phycology, 6, 509-526. http://dx.doi.org/10.1007/BF02182405

[13] Vinogradova, Z.A. and Petkevich, T.A. (1967) Chemical Elemental Content of the Black Sea, Azov Sea and Caspian Sea Plankton. (inrussian). Biochemistry of the Marine Organisms, Kiev, 70-82.

[14] Rozhanskaya, L.I. (1983) Trace Elements in Plankton and Fishes from the Western Part of the Black Sea. (inrussian). Ekologiya Morya, 12, 22-30.

[15] Saenko, G.N. (1992) Metals and Halogens in Marine Organisms. (inrussian). Nauka. M.

[16] Osadchaya, T.S., Ovsyaniy, E.I., Kemp, R., Romanov, A.S. and Ignatieva, O.G. (2003) Organic Carbon and Oil Hydrocarbons in Bottom Sediments of Sevastopol Bay (the Black Sea). Marine Ecological Journal, 2, 94-101.

[17] Frontasyeva, M.V. (2011) Neutron Activation Analysis for the Life Sciences. A Review. Phisika Elementarnikh Chastits i AtomnogoYadra, 42, 332-378.

[18] Chen, G.C., Li, C.W. and Yang, R.S. (1991) Technology of Biological Electron Microscopy. Published by National Science Council, Taiwan, 209-223.

[19] National Research Council (US) (1969) Committee on Oceanography. Biological Methods Panel. Recommended Pro- 
cedures for Measuring the Productivity of Plankton Standing Stock and Related Oceanic Properties. National Academies.

[20] Parkhomenko, A.V., Kuftarkova, E.A., Subbotin, A.A. and Gubanov, V.I. (2003) Results of Hydrochemical Monitoring of Sevastopol Black Sea’s Offshore Waters. Journal of Coastal Research, 19, 907-911.

[21] Dmitriev, A.Yu. and Pavlov, S.S. (2013) Automated Quantitative Determination of Elements in Samples by Neutron Activation Analysis at the IBR-2 at the LNP JINR. Phisika Elementarnikh Chastits $i$ Atomnogo Yadra, 10, 58-64.

[22] Li, Y.H. (1991) Distribution Patterns of the Elements in the Ocean: A Synthesis. Geochim. Cosmochim. Acta, 55, 32233240. http://dx.doi.org/10.1016/0016-7037(91)90485-N

[23] Bobrov, V.A., Phedorin, M.A., Leonova, G.A. and Kolmogorov, Yu.P. (2005) SR XRF Element Analysis of Sea Plankton. Nuclear Instruments and Methods in Physics Research A, 543, 259-265. http://dx.doi.org/10.1016/j.nima.2005.01.218

[24] Angeler, D.G., Salvador, S.-C., Maria, A.R., Miguel, A.-C. and Carmen, R. (2007) Does Seston Size Structure Reflect Fish-Mediated Effects on Water Quality in a Degraded Semiarid Wetland? Environmental Monitoring and Assessment, 125, 9-17. http://dx.doi.org/10.1007/s10661-006-9234-5

[25] White, P.J. and Brown, P.H. (2010) Plant Nutrition for Sustainable Development and Global Health. Annals of Botany, 105, 1073-1080.

[26] Mackenzie, F.T., Stoffyn, M. and Wollast, R. (1978) Aluminum in Seawater: Control by Biological Activity. Science, 199, 680-682.

[27] Morel, F.M.M., Reuter, J.G. and Price, N.M. (1991) Iron Nutrition of Phytoplankton and its Possible Importance in the Ecology of Ocean Regions with High Nutrient and Low Biomass. Oceanography, 4, 56-61. http://dx.doi.org/10.5670/oceanog.1991.03

[28] Cushing, C.E. and Rancitelli, L.A. (1972) Trace Element Analyses of Golumbia River Water and Phytoplankton. Northwest Science, 46, 115-121. 